\title{
Development and Death of External Granular Layer Cells in the Weaver Mouse Cerebellum: A Quantitative Study
}

\author{
Richard J. Smeyne and Dan Goldowitz \\ Department of Anatomy, Thomas Jefferson University, Philadelphia, Pennsylvania 19107
}

\begin{abstract}
Previous studies have identified the cerebellar granule cell as a primary site of gene action in the weaver mutant mouse. The temporal expression of the weaver mutant granule cell phenotype has not been fully investigated. To identify early postnatal expression of the weaver mutant phenotype, we quantitated 4 parameters of cerebellar development in postnatal day $0,2,4,6$, and $8+/+, w v /+$, and $w v / w v$ mice: (1) cerebellar area, (2) cells in the external granule layer (EGL), (3) number of mitotic figures in the EGL, and (4) number of pyknotic figures in the EGL. Qualitative observations suggest a generalized retardation in the development of $w v / w v$ and $w v /+$ EGL cells compared with the $+1+$ cells. Quantitatively, the earliest detectable mutant phenotype in wv/wv and $w v /+$ cerebella is the increased presence of cell death in the EGL, apparent at the day of birth. Degenerating cells in the EGL, the majority of which are found in the postmitotic zone of this layer, contain abnormally clumped heterochromatin, suggestive of "nuclear" cell death. Previous hypotheses concerning the mechanism of weaver gene action have suggested that granule cells die due to their inability to migrate from the EGL. The time course, mode, and spatial organization of cell death found in the present studies lead us to suggest that an earlier event in granule cell development, such as the exit of neuroblasts from the cell cycle or axonogenesis, is affected by the weaver gene.
\end{abstract}

It is believed that the precision by which the nervous system develops has its basis in the timing and cellular specificity of gene expression. Since many genes are being expressed in many cells at varying times in the developing brain, it is difficult to critically examine the role of any one specific gene in development. The study of single gene mutations that affect development provides an elegant solution to this problem. When using genetic mutations in the analysis of nervous system development, however, 2 points must be ascertained: (1) the cellular target(s) of mutant gene action and (2) the temporal course of mutant gene expression. These 2 points of information allow one to assess how the expression of the mutant gene can account for the abnormal phenotypes that are seen in the mutant animal.

\footnotetext{
Received May 5, 1988; revised Oct. 24, 1988; accepted Oct. 26, 1988.

This work is supported by NS 23475 . We thank Drs. Timothy Cunningham, Leonard M. Eisenman, Pat Levitt, and John Heckroth for their critical evaluation of this manuscript, and Richard Rayner for assistance with the preparation of 1 $\mu \mathrm{m}$ material.

Correspondence should be addressed to Dr. Dan Goldowitz at the above address.

Copyright (C) 1989 Society for Neuroscience $0270-6474 / 89 / 051608-13 \$ 02.00 / 0$
}

Numerous single gene mutations that affect the development of the CNS of the mouse have been described (see Sidman et al., 1965; Caviness and Rakic, 1978). One of these mutants is the weaver mouse (gene symbol $=w v$ ). The most striking deficit in the homozygous weaver $(w v / w v)$ cerebellum is a virtual absence of granule cells in the vermis. The heterozygous weaver mouse $(w v /+)$ shows a less severe mutant phenotype with an attenuated loss of cerebellar granule cells (Rakic and Sidman, 1973a). Rezai and Yoon (1972) and Rakic and Sidman (1973a) noted the presence of pyknotic cells in the postmitotic, premigratory zone and suggested that the degeneration of weaver granule cells was the result of their inability to migrate from the external granule layer (EGL) to the internal granule layer (IGL). Early studies, therefore, proposed that the granule cell loss may be secondary to glial defects in the weaver cerebellum (Rakic and Sidman, 1973b). Sotelo and Changeux (1974) noted that some granule cells were able to migrate to the IGL before degeneration, suggesting, to them, that the site of gene action was closer to the granule cell. The notion that the granule cell is a direct site of weaver gene action was supported by the in vitro findings of Willinger and Margolis (1985a, b), who demonstrated that $w v / w v$ granule cells had a lower rate of survival than wildtype granule cells. Goldowitz and Mullen (1982) used $w v /+\leftrightarrow$ $+/+$ chimeras to demonstrate experimentally that the granule cell was a primary site of gene action in the heterozygous weaver mouse. The analysis of interspecific $w v / w v \leftrightarrow+/+$ chimeras demonstrated that despite the presence of $+/+$ Bergmann glia, $w v / w v$ granule cells do not survive. Furthermore, $+/+$ granule cells successfully migrate past $w v / w v$ Bergmann glia (Goldowitz, 1989). Likewise, in an elegant set of studies using an in vitro "chimeric" system, Hatten and colleagues (1986) found that $+/+$ granule cells could successfully attach and migrate along both $w v / w v$ and $+/+$ Bergmann glia, while $w v / w v$ granule cells had an impaired association with $+/+$ or $w v / w v$ radial glia.

Thus, there is substantial evidence to point to the granule cell as a primary site of weaver gene action. The rationale of this study is to examine the cellular events affected by $w v$ gene expression and the time course of these events. Identifying the onset of the weaver mutant phenotype in the framework of normal cerebellar development should suggest which step in granule cell differentiation is affected by the weaver gene. We find that as early as the day of birth (P0) the $w v / w v$ cercbcllum can be differentiated from the $w v /+$ and $+1+$ cerebellum by the amount of cell death present in the EGL. This early expression of the weaver phenotype suggests that an event prior to the physical migration of the granule cells, which starts at around postnatal day 4 (P4) in the $+1+$ mouse (Miale and Sidman, 1961; Fujita et al., 1967), is disrupted by the weaver gene. 


\section{Materials and Methods}

Animals. C57BL/6J mice carrying the heterozygous and homozygous weaver mutant alleles were housed in our animal colony on a 12:12 light-dark cycle. Heterozygous weaver males $(w v /+)$ were mated with heterozygous $(w v /+)$, homozygous $(w v / w v)$ weaver, or wild-type $(+/+)$ females. Pregnant females were checked each morning to determine if they had given birth. Day of birth was considered postnatal day 0 (P0). A total of 83 mice from postnatal days $0,2,4,6$, and 8 were processed for histology.

Perfusion and histology. At 2 day intervals from P0-P8 animals were injected intraperitoneally with an overdose of Avertin. When deeply anesthetized, mice were perfused transcardially with $0.9 \%$ normal saline followed by a modified Bouin's solution (Fraser, 1982). Brains were removed after perfusion and postfixed for $24-48 \mathrm{hr}$ in fresh fixative. After the postfixation, brains were dehydrated and embedded in Paraplast-plus. Sagittal sections of the right hemicerebellum were cut serially at $6 \mu \mathrm{m}$. After every 20th section, 4 consecutive sections were mounted onto $0.5 \%$ gelatin-coated slides and stained using the method of Fraser (1982) or hemotoxyline-eosin. These staining techniques, with the above fixative helped to highlight mitotic figures and pyknotic nuclei. In another series of experiments, $1 \mu \mathrm{m}$ sections were prepared from the cerebellum as previously described (see Goldowitz and Mullen, 1982).

Morphometry/measurement of the developing cerebellum. Of the 83 cerebella qualitatively examined at the light microscopic level, the cerebella from 39 mice were chosen for quantitative measurements. Five features of cerebellar morphogenesis were quantified: (1) cerebellar area/ section, (2) area of the EGL/section, (3) total number of cells in the $\mathrm{EGL} /$ section, (4) number of mitotic figures in the EGL/section, and (5) number of dead/dying cells in the EGL/section. In these studies, 2 regions of the cerebellum were analyzed: vermis and hemisphere. Since the area of the vermis and hemisphere increase in size from P0 to P8, and the borders of these regions are not constant, we measured a 480 $\mu \mathrm{m}$ area which was always a part of vermis or hemisphere at each of the ages examined. The vermal data was derived from the most medial aspect of the cerebellum, spanning a region from the midline to $480 \mu \mathrm{m}$ laterally. This region is characterized by the limited presence of nuclear cells. The hemispheric data presented in this study was derived from the lateral cerebellum, spanning a region from the point where the brain stem and forebrain are first anatomically separated to $480 \mu \mathrm{m}$ medially. This region is characterized by the lateral expansion of the cerebellum and the prominent presence of nuclear cells. In this study, our analysis focused principally on the medial cerebellum, the region most affected by the weaver gene (Herrup and Trenkner, 1987).

Area measurements were made by tracing sections using a drawing tube and a digitizing tablet (Houston Instruments, Inc.), which was interfaced with an Apple-IIe computer and Optomax Semi-Automatic Image Analysis System software (Optomax, Inc.). Area of the cerebellum was measured at $40 \times$ magnification, while area of the EGL was measured at $400 \times$ magnification.

Cell counts were made from 6-8 areas or bins $\left(0.01-0.03 \mathrm{~mm}^{2}\right)$ per section within the EGL. These bins were chosen so that the anteriorto-posterior axis of the cerebellum was equally sampled. In order to count all of the granule cell nuclei, mitotic figures, and pyknotic nuclei in a field, it was necessary to focus throughout the entire thickness of a section, since the granule cell's diameter was smaller than the section thickness. There were approximately 125 cells per bin, so that 750 1000 cells per section were sampled. No significant differences in the cell density existed between the individual bins. Cells in early metaphase through late telophase were counted as mitotic cells (Fig. $4 B$ ). Dead or dying cells were characterized by their condensed chromatin and hyperchromatic nuclei (Fig. $5 \mathrm{C}$ ). For each parameter the bin values were summed for each of 5 sections, and a mean value/section was determined. Total cell number in the EGL was determined by multiplying the cell density of the bins (cells/measured area) by the total area of the EGL:

$$
\frac{\text { Mean cells per bin }}{\text { Mean area per bin }} \times \begin{gathered}
\text { Total area } \\
\text { of the } \\
\text { EGL/section }
\end{gathered}=\begin{gathered}
\text { Number } \\
\text { of EGL } \\
\text { cells/section. }
\end{gathered}
$$

The measures from each of the individual sections were summed and multiplied by 20 (the number of sections between those sections that were analyzed). This estimate was corrected for split nuclei according to the method of Abercrombie (1946), using an empirically determined average nuclear size of $4 \mu \mathrm{m}$. No differences in nuclear diameter were
Table 1. Number of animals in study and mating schemes from which they were derived

\begin{tabular}{lllll} 
Age & $n$ & $\begin{array}{l}w v /+\times \\
+/+\end{array}$ & $\begin{array}{l}w v /+\times \\
w v /+\end{array}$ & $\begin{array}{l}w v /+\times \\
w v / w v\end{array}$ \\
\hline $\mathrm{P} 0$ & & & & \\
$w v / w v$ & 4 & - & $2 a(2)^{b}$ & $2(2)$ \\
$w v / 1$ & 7 & - & $4(0)$ & $3(3)$ \\
$+/+$ & 3 & - & $3(3)$ & 0 \\
$\mathrm{P} 2$ & & & & \\
$w v / w v$ & 4 & 0 & $2(0)$ & $2(2)$ \\
$w v /+$ & 6 & $1(0)$ & $4(1)$ & $1(1)$ \\
$+/+$ & 8 & $4(4)$ & $4(2)$ & 0 \\
$\mathrm{P} 4$ & & & & \\
$w v / w v$ & 5 & - & $2(2)$ & $3(3)$ \\
$w v /+$ & 9 & - & $4(1)$ & $5(1)$ \\
$+/+$ & 3 & - & $3(2)$ & 0 \\
$\mathrm{P} 6$ & & & & \\
$w v / w v$ & 5 & - & $3(1)$ & $2(1)$ \\
$w v /+$ & 9 & - & $5(2)$ & $4(0)$ \\
$+/+$ & 3 & - & $3(1)$ & 0 \\
$\mathrm{P} 8$ & & & $3(0)$ & $2(2)$ \\
$w v / w v$ & 5 & - & $7(2)$ & $1(0)$ \\
$w v /+$ & 8 & - & $4(1)$ & 0 \\
$+/+$ & 4 & - & &
\end{tabular}

Genotypes were assigned on the basis of percentage of pyknotic cells present in the EGL.

a Total number of animals of each genotype qualitatively examined.

${ }^{b}$ The number in parentheses represents the total number of animals quantitatively examined.

seen between the granule cells of the 3 genotypes. The numbers of mitotic cells and dead/dying cells were determined in a similar manner. The clearing rate of the pyknotic figures was determined using the formulas derived by Hughes (1961). Cell counts were made using an oil-immersion objective at a magnification of 1000 .

In order to determine if there were significant differences between or among the 3 groups, an ANOVA was carried out. A Newman-Keuls analysis for differences between groups (Winer, 1961) was performed when significant differences in the ANOVA were found.

\section{Results}

\section{Determination of genotypes}

Based upon previous descriptions of the weaver cerebellum (Rakic and Sidman, 1973a), the 3 genotypes can be easily differentiated at postnatal days 4,6 , and 8 . The mutant phenotype of the weaver cerebellum at earlier ages has not been described, and thus we had no a priori reasons for assuming what a genotypically $w v / w v$ or $w v /+$ cerebellum would look like compared with the $+/+$ cerebellum. To address this point, we searched for an experimental measure (phenotype) that could identify the genotype. P0 and P2 cerebella were examined from pups born from 3 mating schemes: (1) $w v /+\times w v /+$, (2) $w v /+\times w v / w v$, and (3) $w v /+\times+/+$ (see Table 1). In the $w v /+\times w v /+$ mating, we found that only one variable (cell death) clearly fell into 3 distinct groups, as would be predicted by Mendelian segregation. Examination of cerebella from a $w v / w v \times w v /+$ mating showed that the percentage of cell death in the EGL clearly fell into 2 groups, as would be expected from the genotypes used in this mating scheme. The percentages of dead/dying cells from these 2 groups were similar to those of dead/dying cells in presumed 
1610 Smeyne and Goldowitz • Cell Death in the Weaver EGL
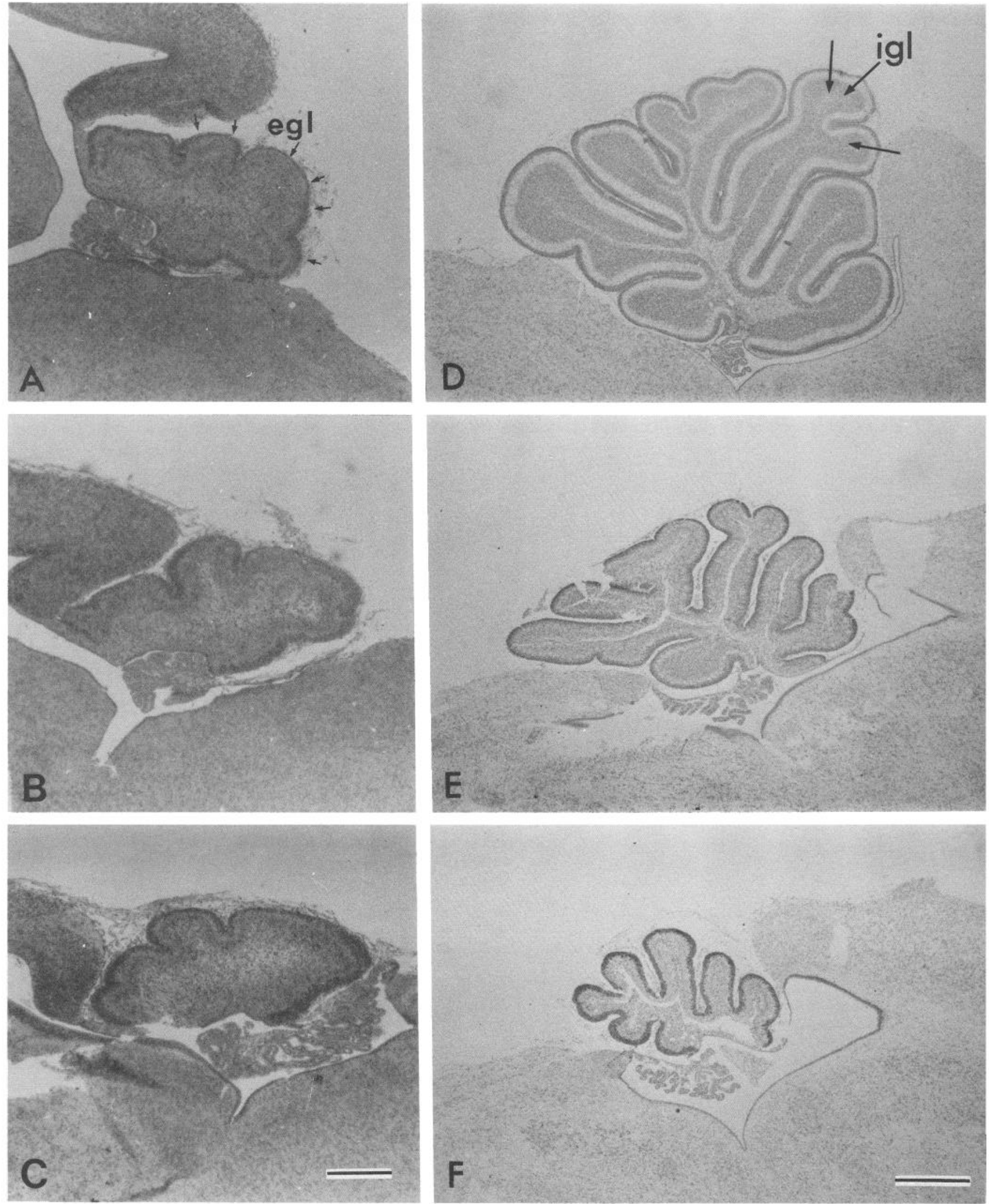

Figure 1. Low-power photomicrographs of $+/+(A, D), w v /+(B, E)$, and $w v / w v(C, F)$ sections from the $\mathrm{P} 0(A-C)$ and $\mathrm{P} 8(D-F)$ cerebellar vermis. At P0, the granule cells are arranged in an external granule layer (egl, arrows). At P8, an internal granule layer (igl, arrows) has formed in both the $+/+$ and $w v /+$. No IGL is present in the P8 $w v / w v$ cerebellum. Scale bars: $A-C, 200 \mu \mathrm{m} ; D-F, 400 \mu \mathrm{m}$. 
AREA/SECTION CEREBELLUM (VERMIS)
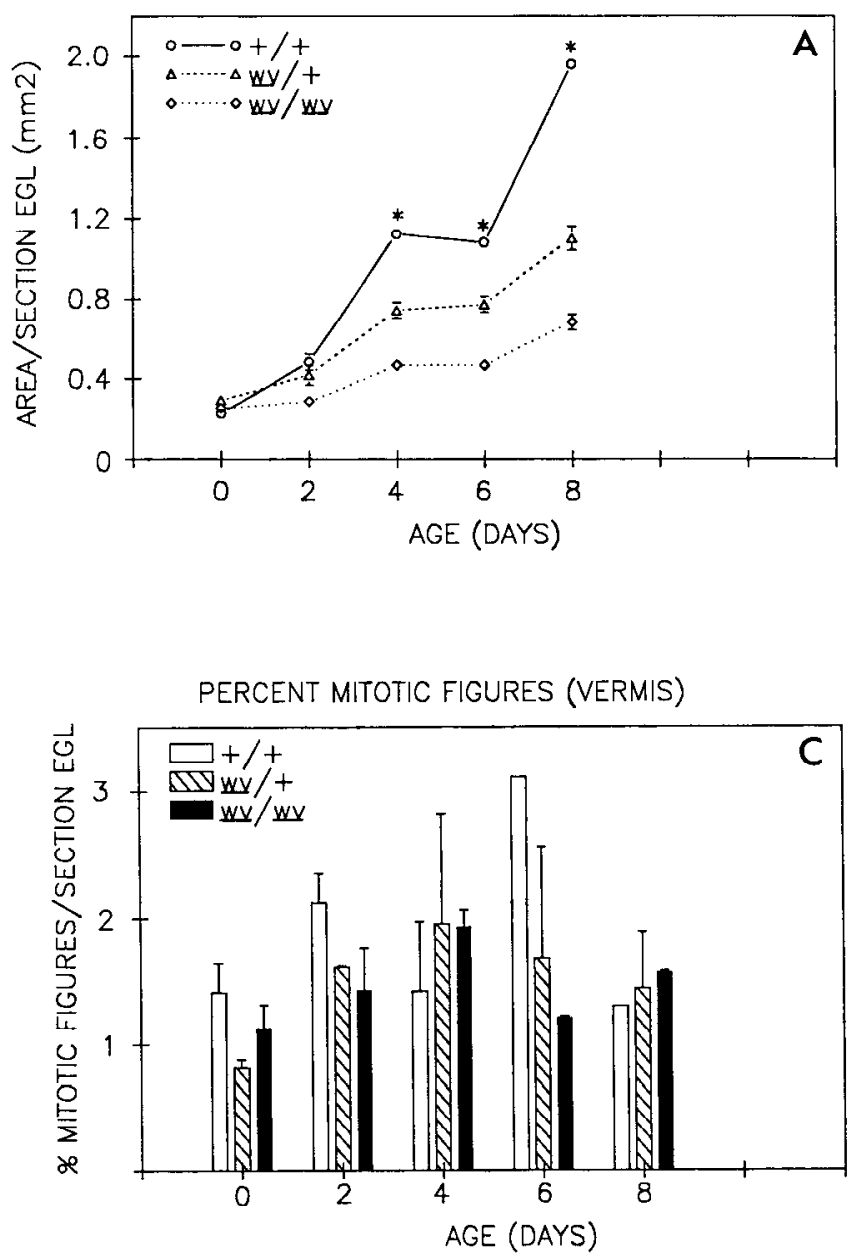

CELLS/SECTION EGL (VERMIS)
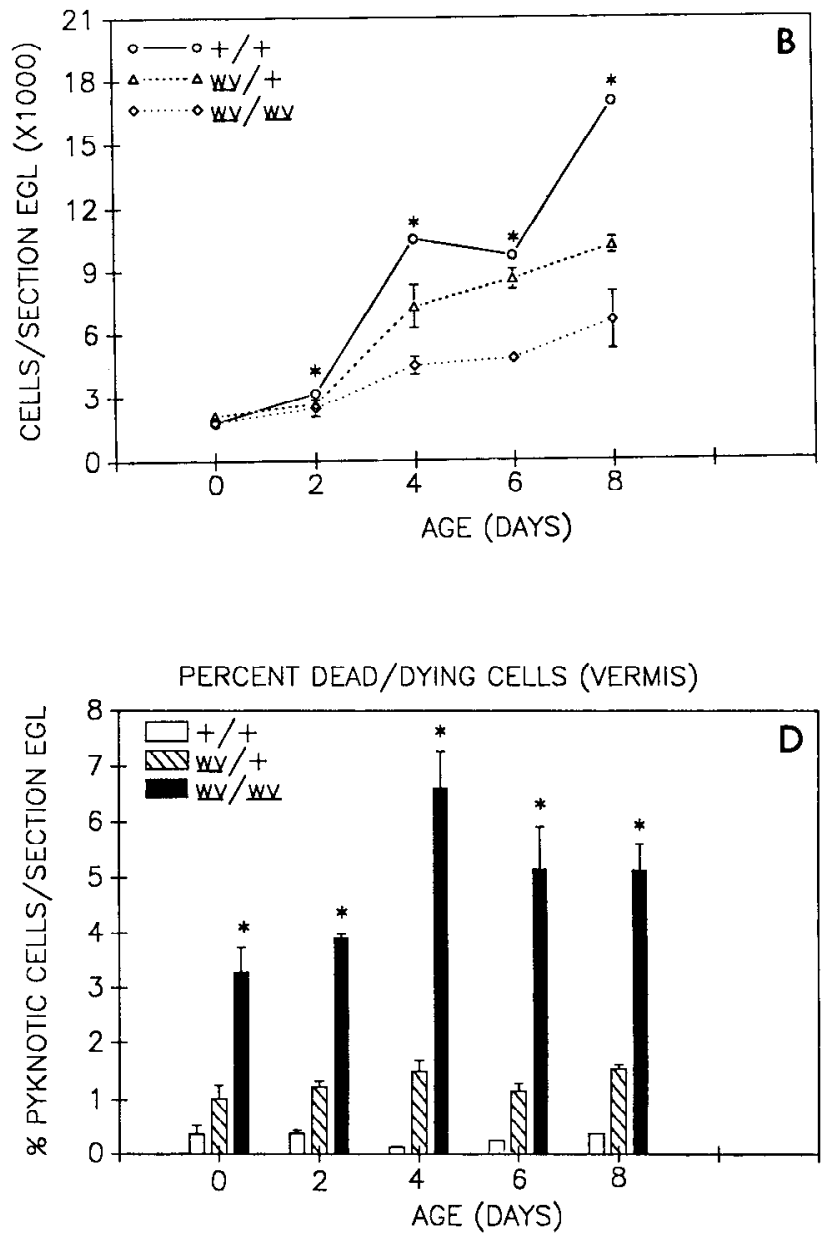

Figure 2. Graphic presentation of devclopment of the $1 /+, w v /+$, and $w v / w v$ cerebellar vermis from P0 to P8. $A$, Area; $B$, cells in the EGL; $C$, mitotic figures in the EGL; $D$, pyknotic cells in the EGL. * ANOVA $(p<0.05)$.

$w v / w v$ and $w v /+$ genotypes found from the $w v /+\times w v /+$ matings. Finally, the $w v /+x+/+$ mating yielded 2 distinct groups that were also similar to the percentages of dead/dying cells in the presumed $w v /+$ and $+/+$ found in the $w v /+\times w v /+$ matings. Thus, each animal at $\mathrm{P} 0$ and $\mathrm{P} 2$ could be assigned a genotype based upon the phenotype of cell death, and all of the other phenotypes could be compared relative to this assigned genotype.

\section{The wild-type cerebellum $(+/+)$}

Sagittal sections through the $\mathrm{P} 0$ vermis reveal 5 large lobules (Fig. 1A). More laterally, fissures are just starting to separate the cerebellum into lobules. From $\mathrm{P} 0$ through $\mathrm{P} 2$, the area of the cerebellar vermis increases slightly (Fig. $2 A$ ). From $\mathrm{P} 2$ through $\mathrm{P} 4$, the vermis undergoes a rapid period of growth. This growth is most apparent in the vermis, which shows a 3-fold increase between P2 and P4 (Table 2). In contrast, the area/section of the cerebellar hemispheres only increases about $130 \%$ (see Fig. $3 A$ ). From P4 through P8, the vermal area doubles. Cerebellar growth is mainly in the dorsal-ventral and anterior-posterior dimensions (the anterior-posterior extent of the vermis increases approximately $900 \%$ from P0-P8). The medial-lateral extent of the entire cerebellum at P8 is only $60 \%$ greater than at $\mathrm{P} 0$. At P8, the adult number of lobules is present in the vermis (Fig. 1D).

The subpial surface of the early postnatal cerebellum is covered by numerous, closely packed cells that compose the EGL (Fig. $4 A$ ). At P0, the EGL is $3-4$ cells thick. Occasional mitotic figures are present throughout the entire thickness of the EGL (from pia to the nascent molecular layer). By P2, the EGL has grown to 4-6 cells in thickness, with a comcomitant 2 -fold rise in the number of cells in the EGL (Fig. 2B; Table 3). Mitotic figures are, as before, seen throughout the thickness of the EGL. The mitotic index of the EGL ranges from 1 to $2 \%$ (Table 4). In the deepest layers of the EGL, at the molecular layer (ML) interface, some of the granule cells have started to change from a round to an elongated spindle shape. This change in cell morphology is consistent with changes seen in neurons that are beginning their migration (Fig. 4A) (Ramón y Cajal, 1960; Rakic, 1971; Trinkhaus, 1984). By P2, a few cells are seen within the molecular layer. The EGL, however, remains a compact zone. The EGL at P4-P8, which increases to 8-10 cells in thickness, can be separated into 2 zones: a superficial zone (approximately $1 / 3$ of the EGL) that contains the majority of the mitotically active, rounded cells, and a deeper zone (approximately $2 / 3$ of the EGL) containing both round and elongated cells. This 


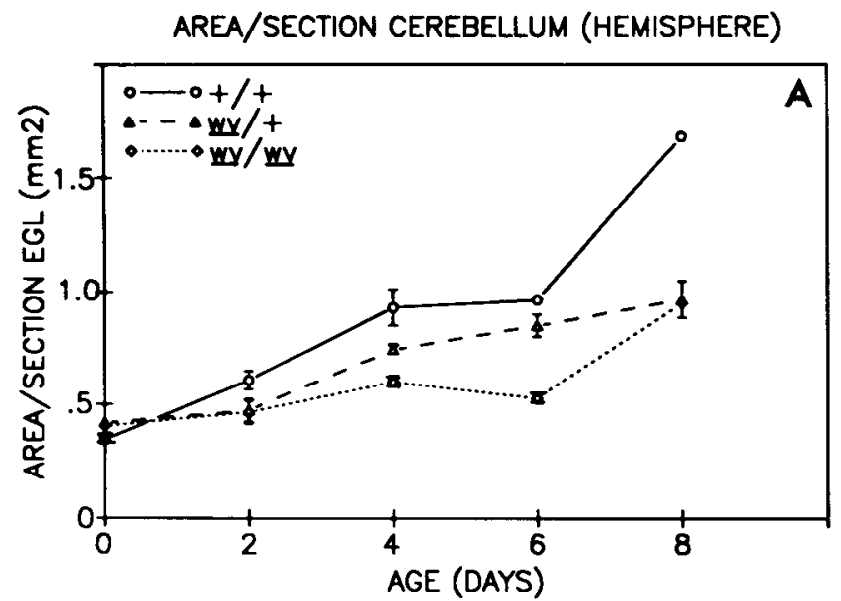

PERCENT MITOTIC FIGURES (HEMISPHERE)

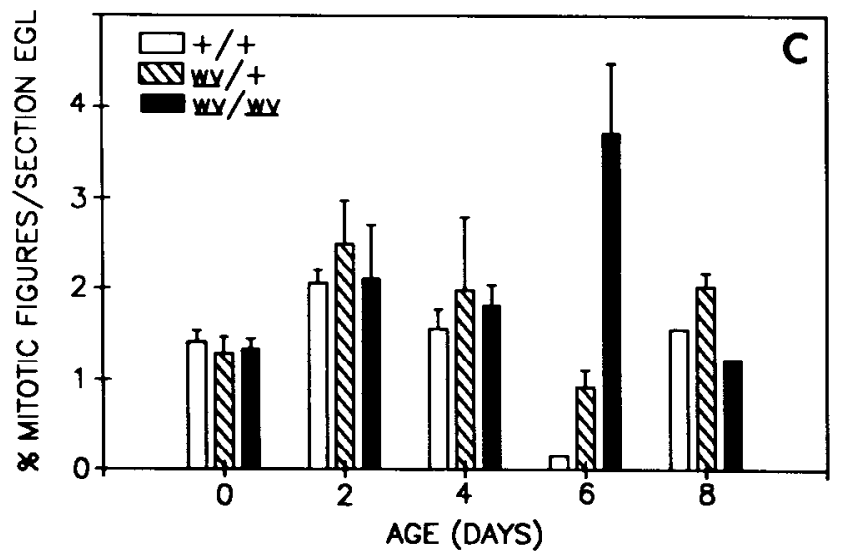

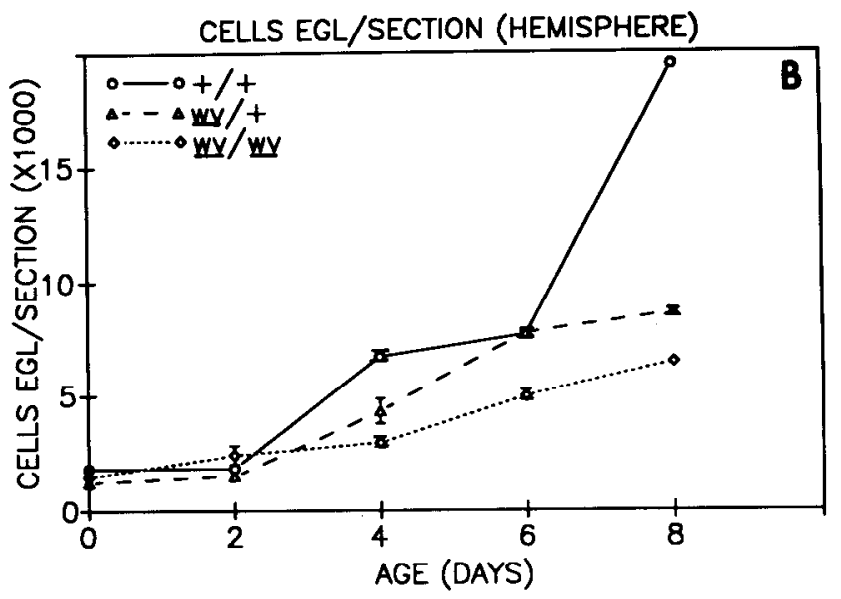

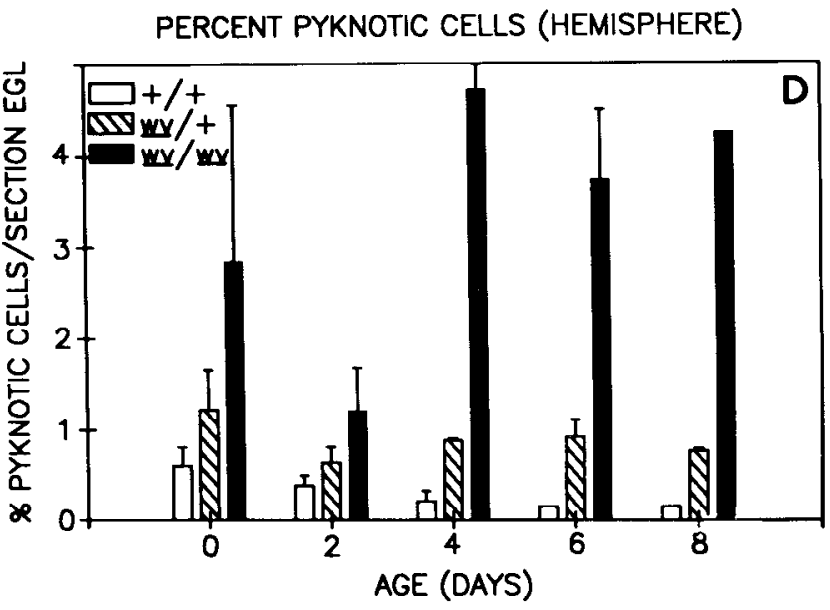

Figure 3. Graphic presentation of development of the $+/+, w v /+$, and $w v / w v$ cerebellar hemispheres from P0 to P8. $A$, Area; $B$, cells in the EGL; $C$, mitotic figures in the EGL; $D$, pyknotic cells in the EGL.

deeper zone is not as compacted as the mitotically active zone (Fig. 4D).

As previously described by Mares and coworkers (1970), pyknotic nuclei are occasionally seen within the EGL of the wildtype mouse from P0 through P8 (Table 5). The majority of these pyknotic cells are found in the deep layers of the EGL (at the EGL/ML interface), although some are found at more superficial levels. The pyknotic cells in the EGL are scattered and rarely found in clusters (Fig. 5A).

\section{Heterozygous weaver mouse (wv/+) cerebellum}

At $\mathrm{P} 0$, the area/section of the $w v /+$ cerebellum is equal to that of the $+/+$ mouse (Figs. $2 A, 3 A$ ). The lobular arrangement of the $w v /+$ and $+/+$ cerebellum is similar (Fig. $1 B$ ). Like the $+/+$ vermis, the cross-sectional area of the $w v /+$ vermis increases only slightly (40\%) from P0 to P2 (Table 2). From P2 to $\mathrm{P} 4$ there is an increased rate of growth, although less than that seen in the wild-type mouse, such that the area/section of the $w v /+$ vermis is $33 \%$ smaller than the vermal area/section of the $+/+$ cerebellum. From P4 to P8, the area/section of the $w v /+$ vermis develops at a slower pace than in the $+/+$ cerebellum, so that by $\mathrm{P} 8$, the area of the $w v /+$ vermis is $57 \%$ of the $+/+$ vermis (Fig. $1 E$, Table 2). Similarly, the cerebellar hemispheres of the $w v /+$ are $37 \%$ smaller than those of the
$+/+$ cerebellum (Fig. 3A). The total width of the cerebellum, at $\mathrm{P} 8$, is decreased by $13 \%$ in the $w v /+$ animal compared with the $+/+$ animals.

At $\mathrm{P} 2$, differences between the $w v /+$ and $+/+$ are seen in the mean number of cells/section in the vermal EGL (Fig. $2 B$; Table $3)$. The vast majority of these $w v /+$ EGL cells appear round. Very few spindle-shaped cells are seen in the deep portions of the EGL (Fig. 4B). As in the $+/+$ mouse, mitotic figures are present throughout all layers of the EGL. Postnatal day 4 is the time at which appreciable numbers of granule cells at the EGL/ ML interface start to elongate. This initial migration of granule cells is similar to that seen in the $\mathrm{P} 2+/+$ cerebellum. Although a great majority of these cells do not move away from the compacted EGL, a few cells are seen in the molecular layer (Fig. $4 E$ ). More migrating granule cells are seen in the $w v /+$ cerebellum at postnatal day 6 . By P8, the EGL of the $w v /+$ cerebellum can be divided into a proliferative zone and a postproliferative zone, similar to that of the $+/+$ mouse.

The number of mitotic figures in the $w v /+$ cerebellum, like the $+/+$, is approximately $1-2 \%$ of the total number of cells within the EGL (Figs. $2 C, 3 C$, Table 4).

Pyknotic nuclei, which are only rarely seen in the $+/+$ animals, are more abundant at all times in the $w v /+$ EGL (Figs. $2 D, 3 D$, Table 5). Before $\mathrm{P} 4$, the dead/dying cells are located 
Table 2. Mean area vermis/section $\left(\mathrm{mm}^{2}\right)$

\begin{tabular}{|c|c|c|c|c|}
\hline \multirow[b]{2}{*}{ Age } & \multicolumn{3}{|l|}{ Genotype } & \multirow{2}{*}{$\begin{array}{l}\text { Signifi- } \\
\text { cance }^{c}\end{array}$} \\
\hline & $+/+$ & $w v /+$ & $w v / w v$ & \\
\hline P0 & $\begin{array}{l}0.225(3)^{a} \\
{[0.217-0.259]^{b}}\end{array}$ & $\begin{array}{l}0.292(3) \\
{[0.252-0.341]}\end{array}$ & $\begin{array}{l}0.252(3) \\
{[0.240-0.268]}\end{array}$ & - \\
\hline $\mathbf{P} 2$ & $\begin{array}{l}0.483(6) \\
{[0.360-0.642]}\end{array}$ & $\begin{array}{l}0.419(2) \\
{[0.367-0.474]}\end{array}$ & $\begin{array}{l}0.286(2) \\
{[0.262-0.309]}\end{array}$ & - \\
\hline P4 & $\begin{array}{l}1.12(2) \\
{[1.10-1.13]}\end{array}$ & $\begin{array}{l}0.743(2) \\
{[0.741-0.744]}\end{array}$ & $\begin{array}{l}0.467(4) \\
{[0.446-0.503]}\end{array}$ & 2,5 \\
\hline P6 & $1.08(1)$ & $\begin{array}{l}0.773(2) \\
{[0.733-0.813]}\end{array}$ & $\begin{array}{l}0.468(2) \\
{[0.439-0.468]}\end{array}$ & 2,3 \\
\hline P8 & $1.96(1)$ & $\begin{array}{l}1.10(2) \\
{[1.04-1.10]}\end{array}$ & $\begin{array}{l}0.683(2) \\
{[0.641-0.725]}\end{array}$ & 2,3 \\
\hline
\end{tabular}

${ }^{a}$ Mean area cerebellum/section vermis $\left(\mathrm{mm}^{2}\right)$. In parentheses is the number of animals used for the study.

${ }^{b}$ Range of measurements in brackets.

'Statistical analyses comparing $+/+, w v /+$, and $w v / w v$ from P0-P8. An ANOVA was performed at each of the ages. If statistical significance was found, a posteriori Newman-Keuls analysis was performed. Below is a key to explain the levels of significance for each of the comparisons:

1 , ANOVA, $p<0.05$.

2, ANOVA, $p<0.01$.

3 , Newman-Keuls $+1+, w v /+$, and $w v / w v$ significantly different, $p<0.05$.

4 , Newman-Keuls $+/+, w v /+$, and $w v / w v$ significantiy different, $p<0.01$.

5, Newman-Keuls $w v /+$ and $w v / w v$ significantly different from $+/+, p<0.05$.

6 , Newman-Keuls $w v / w v$ significantly different from $w v /+$ and $+/+, p<0.05$.

throughout the EGL, although they tend to predominate in the inner $1 / 3$. These dead/dying cells are most typically found as individual cells rather than in clusters. At P4, a band of darkly staining pyknotic nuclei becomes apparent at the EGL/ML interface. In the $\mathrm{P} 4$ vermis, the dead/dying cells are seen more in the anterior lobules than in the posterior lobules. In the cerebellar hemispheres of the $w v /+$ mouse, approximately $40 \%$ fewer pyknotic nuclei are seen compared with the vermis (Figs. $2 D$, $3 D$ ). From P4 through P8, pyknotic cells are found in both the EGL and the molecular layer of the vermis (Fig. $6 B$ ).

The molecular layer of the $w v /+$ cerebellum is thin and relatively acellular at $\mathrm{P} 4$. This is unlike the $+/ t$, where many migrating cells are seen in the molecular layer of the $\mathrm{P} 4$ cerebellum. By P6, in the $w v /+$, cells have started to migrate from the EGL through the ML, forming a recognizable IGL. The molecular layer of the P6 wv/+ cerebellum appears to be hypercellular compared with the P6 $+/+$ cerebellum. This hypercellularity of the molecular layer in the $w v /+$ mouse is also seen at P8 (Fig. 6, $A, B$ ).

\section{The homozygous weaver (wv/wv) cerebellum}

The $w v / w v$ cerebellum at $\mathbf{P} 0$ has a similar appearance to that of the $w v /+$ and $+/+$ cerebella with no detectable differences in the width or area/section of the cerebellum (Figs. $1 C, 2 A, 3 A$, Table 2). The area of the vermis in the $w v / w v$ increases from P0 to P2, although the growth is only 46 and $69 \%$ of that seen in the $+/+$ and $w v /+$ cerebellum, respectively (Fig. $2 A$ ). The vermis, at $\mathbf{P} 4$, is $48 \%$ of the size of the $+/+$ vermis (Table 2 ). This is similar to the situation in the $w v / w v$ hemisphere (see Fig. $3 A$ ). By $\mathrm{P} 8$, the area/section of the vermis is $65 \%$ smaller
Table 3. Mean number of EGL cells in the vermis/section

\begin{tabular}{lllll} 
& \multicolumn{2}{l}{ Genotype } & & \multicolumn{2}{l}{$\begin{array}{l}\text { Signifi- } \\
\text { cance }^{c}\end{array}$} \\
\cline { 2 - 5 } P0 & $1750(3)^{a}$ & $w v /+$ & $w v / w v$ & - \\
& {$[1620-2020]^{b}$} & {$[1750-2020]$} & {$[1600-2180]$} &
\end{tabular}

$\begin{array}{lllll}\text { P2 } & 3160(6) & 2660(2) & 2470(2) & 1,6 \\ & {[2960-3390]} & {[2480-2830]} & {[2080-2860]} & \end{array}$

$\begin{array}{lllll}\text { P4 } & 10,500(2) & 7310(2) & 4470(4) & 2,3 \\ & {[10,400-10,500]} & {[6270-8340]} & {[3980-5710]} & \\ \text { P6 } & 9700(1) & 8600(2) & 4820(2) & 1,5 \\ & & {[8130-9070]} & {[4710-4930]} & \\ \text { P8 } & 17,000(1) & 10,200(2) & 6620(2) & 1,5 \\ & & {[9810-10,600]} & {[5230-8010]} & \end{array}$

${ }^{a}$ Mean number of cells/section EGL vermis. In parentheses is the number of animals used for the analysis.

"Range of measurements in brackets.

'Statistical analysis comparing $+/+, w v /+$, and $w v / w v$ from P0-P8. For explanation of levels of significance, see Table 2.

than the wild-type cerebellum (Figs. $1 F, 2 A$ ). The area/section of the P8 $w v / w v$ hemispheres is reduced in size by $23 \%$ from that of the $+/+$ cerebellum (Fig. $3 A$ ). The total width of the cerebellum in the $w v / w v$ mouse at $\mathrm{P} 8$ is reduced 10 and $18 \%$ compared with the $w v /+$ and $+/+$, respectively.

No differences are seen in the total number of EGL cells/ section in the P0 $w v / w v$ mouse compared with the $+/+$ and $w v /+$ cerebella (Figs. $2 B, 3 B$, Table 3 ). By $\mathbf{P} 2$, there is a decreased number of vermal EGL cells/section in $w v / w v$ compared with $+1+$ mice. This difference becomes more striking at P4 (Table 3 ). Unlike the $w v /+$ or $+/+$ cerebella, no spindle-shaped cells are seen in the deep layers of the EGL (Fig. 4C). The EGL

\begin{tabular}{|c|c|c|c|c|}
\hline \multirow[b]{2}{*}{ Age } & \multicolumn{3}{|l|}{ Genotype } & \multirow{2}{*}{$\begin{array}{l}\text { Signifi- } \\
\text { cance }^{c}\end{array}$} \\
\hline & $+1+$ & $w v /+$ & $w v / w v$ & \\
\hline $\mathrm{P} 0$ & $\begin{array}{l}1.41(3)^{a} \\
{[1.14-1.88]^{b}}\end{array}$ & $\begin{array}{l}0.82(3) \\
{[0.71-0.93]}\end{array}$ & $\begin{array}{l}1.13(3) \\
{[0.70-1.59]}\end{array}$ & - \\
\hline P2. & $\begin{array}{l}2.12(6) \\
{[1.56-2.83]}\end{array}$ & $\begin{array}{l}1.61(2) \\
{[1.60-1.62]}\end{array}$ & $\begin{array}{l}1.43(2) \\
{[1.10-1.77]}\end{array}$ & - \\
\hline P4 & $\begin{array}{l}1.42(2) \\
{[0.87-1.97]}\end{array}$ & $\begin{array}{l}1.95(2) \\
{[1.08-2.82]}\end{array}$ & $\begin{array}{l}1.93(4) \\
{[1.71-2.26]}\end{array}$ & - \\
\hline P6 & $3.11(1)$ & $\begin{array}{l}1.68(2) \\
{[0.80-2.57]}\end{array}$ & $\begin{array}{l}1.21(2) \\
{[1.20-1.23]}\end{array}$ & - \\
\hline P8 & $1.30(1)$ & $\begin{array}{l}1.44(2) \\
{[0.99-1.90]}\end{array}$ & $\begin{array}{l}1.58(2) \\
{[1.57-1.58]}\end{array}$ & - \\
\hline
\end{tabular}

a Mean percentage of mitotic figures/section in the vermis. The number in parentheses is the number of animals used for this study.

${ }^{b}$ Range of measurements in brackets.

'Statistical analysis comparing $+/+, w v /+$, and $w v / w v$ from P0-P8. For explanation of levels of significance, see Table 2. 

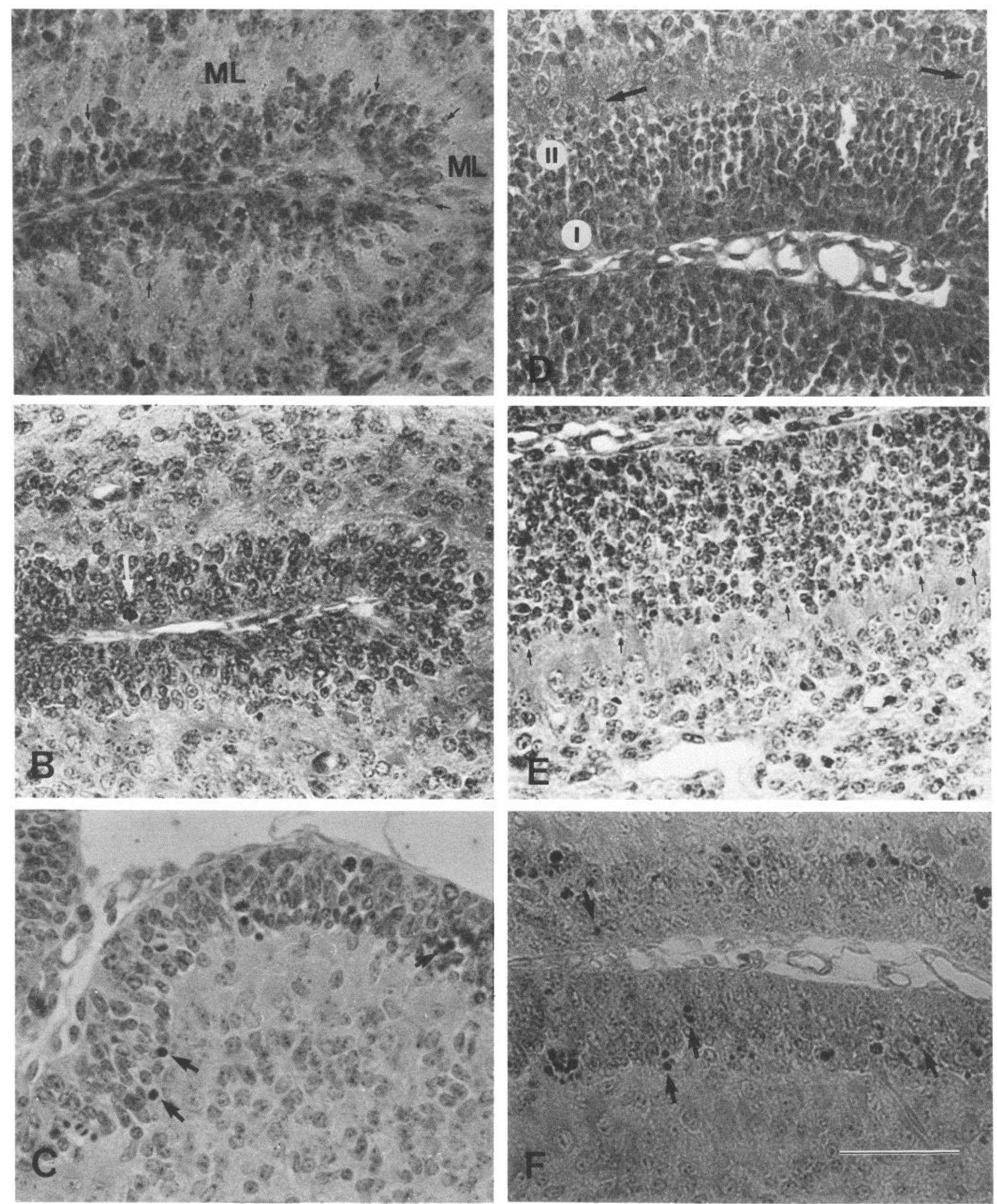

Figure 4. Development of the external granule layer of the $+/+(A, D), w v /+(B, E)$, and $w v / w v(C, F)$ cerebellar vermis. $A$, In the P2 $+/+$ cerebellum, some of the granule cells at the interface of the EGL and the molecular layer $(M L)$ are starting to elongate (arrows). Some of these cells have started to migrate into the molecular layer. $B$, This section shows the EGL of the P2 $w v /+$. In contrast to the $+/+$ cerebellum, fewer spindleshaped cells are present at the EGL/ML interface. A mitotic figure is present near the pial surface of the cerebellum (white arrow). $C$, This section of the P4 wv/wv EGL shows that the EGL remains a compact zone, with an absence of spindle-shaped cells at the EGL/ML interface. Dead and dying cells are usually found in the deeper layers of the EGL (arrowheads). $D$, The EGL of the P4 $+1+$ vermis has expanded into 2 zones, a compact 
of the $w v / w v$ mouse remains a compact zone through postnatal day 8 , although occasional cells can be seen between the compacted EGL and the Purkinje cells. In the P8 cerebellar hemispheres some spindle-shaped cells are seen in the deep portions of the EGL.

Mitotic figures are present throughout the compacted EGL from P0 through P8. The percentage of mitotic figures present in the $w v / w v$ vermis is similar to that found in the $+1+$ and $w v /+$ mice-typically between $1-2 \%$ (Fig. $2 C$, Table 4 ).

The percentage of pyknotic nuclei in the $w v / w v$ EGL is dramatically increased over the $w v /+$ and $+/+$ cerebella at all ages studied in both the vermis and the hemisphere (Figs. $2 D, 3 D$, Table 5). The percentage of cell death is increased in the vermis relative to that of the hemisphere (Figs. $2 D, 3 D$ ). At P0, the number of dead/dying cells is approximately 10 -fold higher than that seen in the $+/+$ EGL. A majority of these dead/dying cells are present in the inner third of the EGL, although these hyperchromatic cells can be found at all levels in the EGL (Fig. $5, B, C)$. The dead and dying cells in the P0 $w v / w v$ cerebellum are most numerous in the posterior lobules (Fig. $5 B$ ), and these pyknotic cells, in $1 \mu \mathrm{m}$ plastic sections, nicely demonstrate different stages of cell death (Fig. 5C). At PO, the early form of cell death predominates, characterized by abnormal clumping of heterochromatin (see Fig. 5C) (Cunningham, 1982). At P2, these pyknotic cells form a noticeable band present at the EGL/ ML interface. By P4, some of the pyknotic cells at the EGL/ $\mathrm{ML}$ interface are found in clusters that incur into the molecular layer. At P6 and P8, the dead/dying cells within the $w v / w v$ EGL are predominantly found in such clusters (Figs. $4 F, 6 C$ ). The majority of these pyknotic cells are in the late stages of cell death, characterized by nuclear fragmentation (see Fig. $5 \mathrm{C}$ ). At P8 the percentage of dead and dying cells in the hemisphere is slightly lower than that of the vermis $(4.26$ and $5.16 \%)$.

The molecular layer of the $w v / w v$ cerebellum remains thin and relatively acellular from $\mathrm{P} 0$ through $\mathrm{P} 6$. At P6, some rounded cells can be seen to be separate from the EGL in the molecular layer. Those cells that are seen in the molecular layer remain rounded and do not have the typical appearance of migrating cells.

\section{Discussion}

The cellular event perturbed in the developmental history of the weaver cerebellar granule cell is unknown. To approach this problem we quantitatively examined the cerebellar granule cell precursor population of $+/+, w v /+$, and $w v / w v$ mice from $\mathrm{P} 0$ to $\mathrm{P} 8$. We find that at $\mathrm{P} 0$, the weaver phenotype of cell death is already expressed in the EGL, suggesting that the event in granule cell differentiation which is affected by the weaver gene occurs prior to the physical migration of the granule cells at P4.

Previous studies of weaver cerebellar development have not reported phenotypic differences prior to P4 (Rezai and Yoon, 1972; Rakic and Sidman, 1973a). Thus, we needed to confidently determine the genotype of each of the animals used in this study. The assignment of genotype was predicated on establishing differences within the granule cell population between $+/+, w v /+$, and $w v / w v$ cerebella. As presented in Results, we
Table 5. Percent dead/dying cells/section (vermis)

\begin{tabular}{lllll} 
& Genotype & & & $\begin{array}{l}\text { Signifi- } \\
\text { cance }^{c}\end{array}$ \\
\cline { 2 - 5 } Age & $+/+$ & $w v /+$ & $w v / w v$ & 1,6 \\
P0 & $0.36(3)^{a}$ & $1.02(3)$ & $3.30(3)$ & \\
& {$[0.06-0.54]^{b}$} & {$[0.67-1.5]$} & {$[2.06-4.14]$} & \\
P2 & $0.37(6)$ & $1.23(2)$ & $3.92(2)$ & 1,3 \\
& {$[0.08-0.53]$} & {$[1.12-1.35]$} & {$[3.83-4.01]$} & \\
P4 & $0.12(2)$ & $1.50(2)$ & $6.62(4)$ & 1,6 \\
& {$[0.11-0.14]$} & {$[1.31-1.70]$} & {$[4.73-7.68]$} & \\
P6 & $0.25(1)$ & $1.16(2)$ & $5.17(2)$ & 2,6 \\
& & {$[1.02-1.31]$} & {$[4.42-5.92]$} & \\
P8 & $0.37(1)$ & $1.54(2)$ & $5.16(2)$ & 2,6 \\
& & {$[1.46-1.62]$} & {$[4.71-5.62]$} &
\end{tabular}

a Mean percentage of pyknotic cells/section vermis. The number in parentheses is the number of animals used for the study.

"Range of measurements in brackets.

Statistical analysis comparing $+/+, w v /+$, and $w v / w v$ from $\mathrm{P} 0-\mathrm{P} 8$. For explanation of levels of significance, see Table 2.

used 3 mating schemes to generate mice of restricted genotypes. The increased incidence of cell death was the only variable examined that enabled us to distinguish between the 3 genotypes at $\mathrm{P} 0$. At $\mathrm{P0}$ and $\mathrm{P} 2$, there were 3 distinct levels of cell death, and these correlated with the expected genotypes from progeny of the various mating schemes. Within each of these 3 groups there was little variability in the percentage of EGL cell death as might be expected if cell death is controlled by the expression of a gene with complete penetrance.

\section{Development of the weaver $E G L$}

The present qualitative observations of the development of the $w v /+$ and $w v / w v$ cerebellum after P4 agree with previously published descriptions (Rezai and Yoon, 1972; Rakic and Sidman, 1973a, b; Sotelo and Changeux, 1974). In this study, we have identified 2 mutant phenotypes present within the EGL population prior to P4: (1) a delay in granule cell migration and (2) an increase in cell death in the EGL.

Granule cells at the EGL/ML interface of the $+/+$ cerebellum start to elongate in preparation for migration at around $\mathrm{P} 2$. This process is delayed for approximately 2 days in the $w v /+$ vermis and is rarely seen in the $w v / w v$ cerebellum. The $w v /+$ granule cells appear to have an impeded developmental program that not only results in a $2 \mathrm{~d}$ delay in the start of migration but also in a longer transit time of granule cells through the molecular layer (Rezai and Yoon, 1972). This retardation in the migratory process results in a hypercellular molecular layer that is apparent by P6.

Both Rezai and Yoon (1972) and Rakic and Sidman (1973a, b) noted the increased presence of pyknotic cells in the EGL of

zone near the pial surface $(I)$ and a looser zone of cells near the EGL/ML interface $(I I)$. Spindle-shaped cells as well as migrating cells are present within the molecular layer (arrows). E. This section from the P4 wv/+ shows that the EGL has grown in width but has not clearly separated into the 2 distinct zones. Spindle-shaped cells first become prevalent at the EGL/ML interface at this time (arrows). $F$, This section of the P8 wv/wv shows that the EGL remains a compact zone with pyknotic nuclei present throughout all levels of the EGL (arrows). Scale bars: $A-F, 50 \mu \mathrm{m}$. 

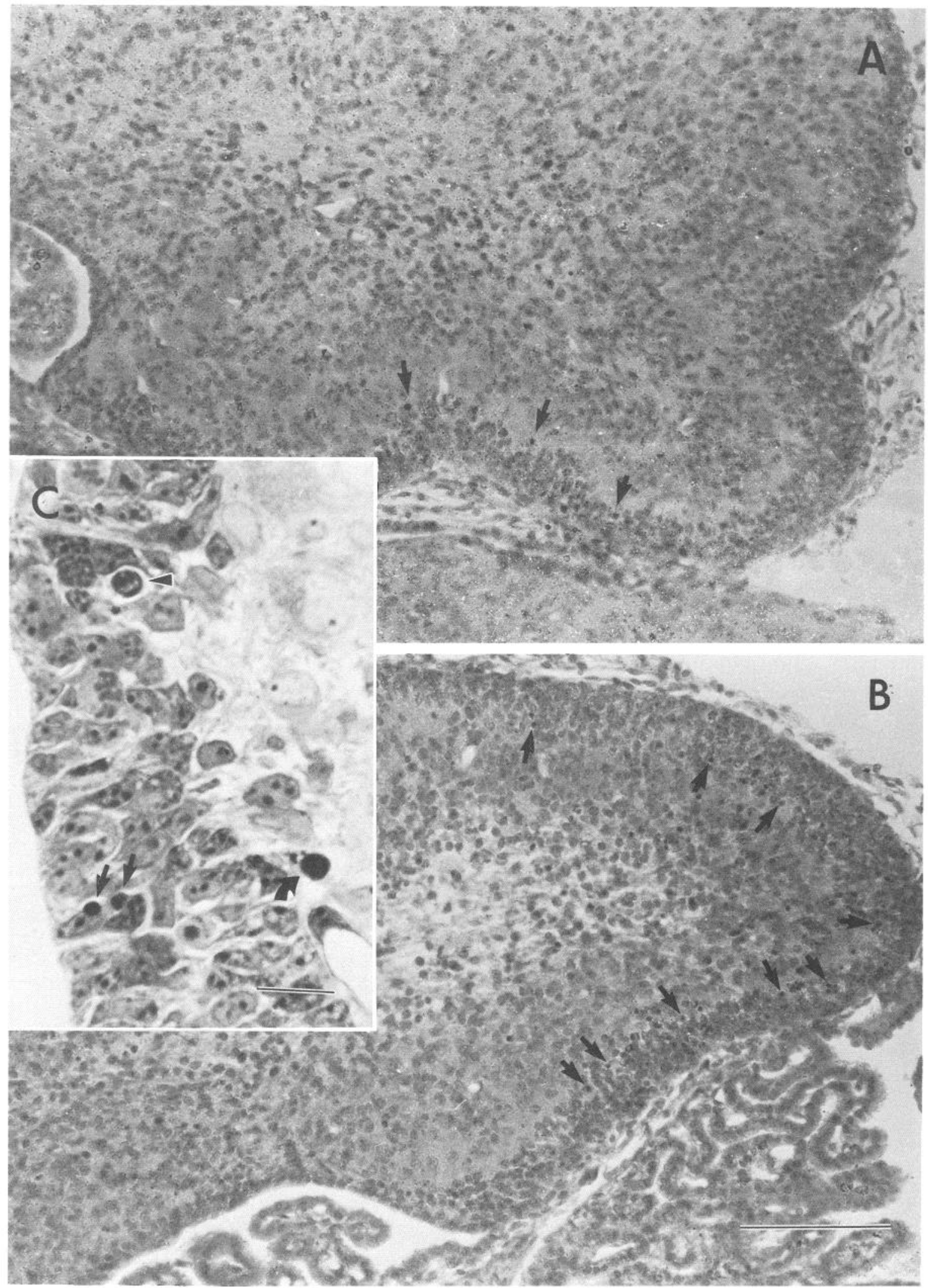

Figure 5. Cell death in the EGL of the $+/+(A)$ and $w v / w v(B, C)$ from the P0 cerebellum. $A$, Cell death in the $\mathrm{P} 0+/+$ cerebellum, although rare, is equally present throughout the anterior and posterior extent of the EGL (arrows). B, Cell death in the posterior lobules of the P0 wv/wv cerebellum (arrows) is increased above that seen in the $+/+$ cerebellum. $C$, Photomicrograph of $1 \mu$ m plastic section showing pyknotic nuclei present in the posterior lobules of the $w v / w v$ EGL. Three stages of cell death can be seen: (1) early (black arrowhead), intermediate (curved black arrow), and late (black arrows). Scale bars: $100 \mu \mathrm{m}$. Calibration bar $(C)=10 \mu \mathrm{m}$. 

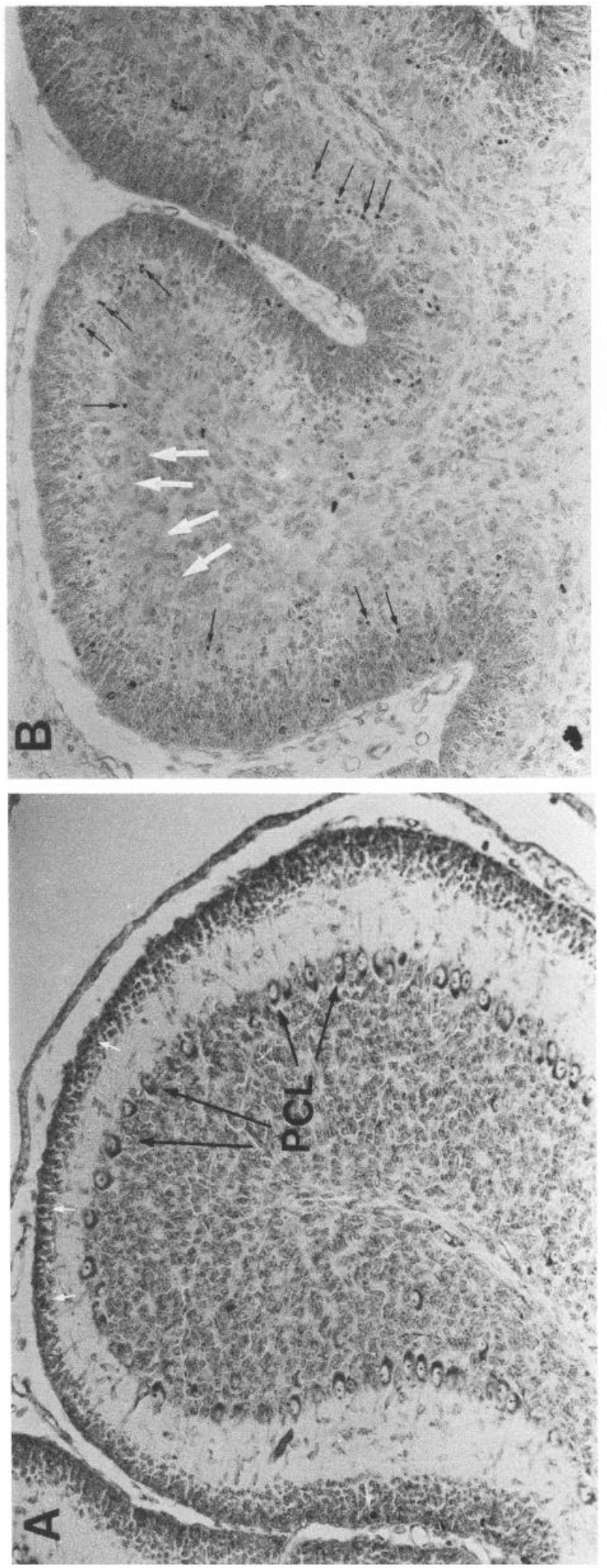

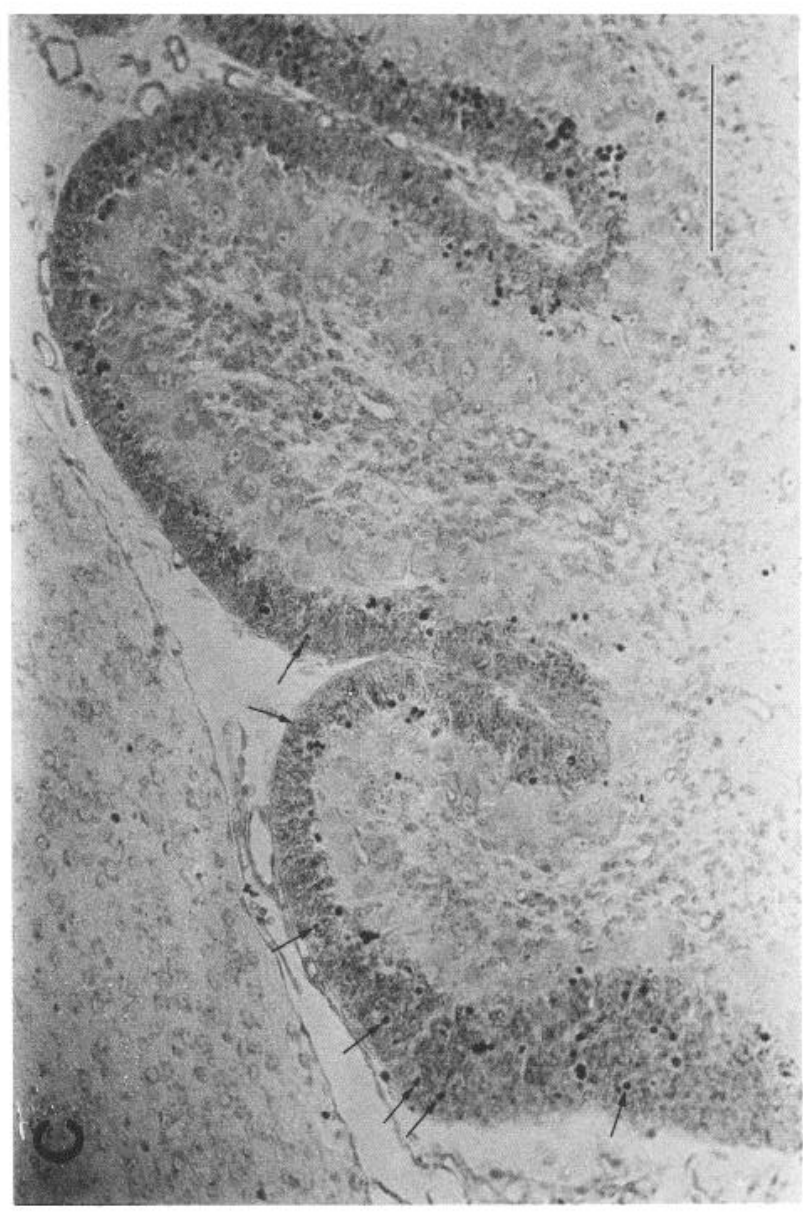

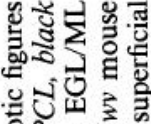

oㄴ?

है

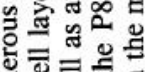

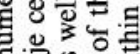

节 娄

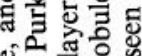

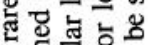

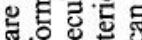

눙

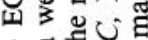

+ 过

을

ज

की

要呵

웅

娄

से

8 .

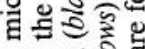

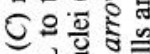

덜웡

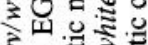

舟

毛统总

-

of

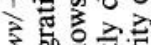

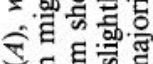

$+\mathrm{W}^{2}$

$+8 \%$

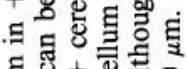

再+

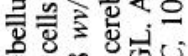

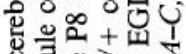

$\infty$ 욜

- ․․․․

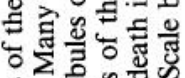

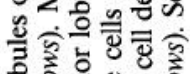

을열.을

क 死

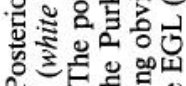

Q

-

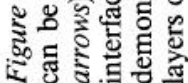


$w v /+$ and $w v / w v$ cerebella after P4. From P4 to P20 (the time of EGL disappearance), the majority of the pyknotic cells are present in the postproliferative mantle zone (Rakic and Sidman, 1973a, b). Prior to P4, we find that the positions of the pyknotic cells are not as segregated as seen after P4. At the early ages, pyknotic cells are distributed throughout the radial extent of the EGL. Thus, the EGL of the P0 and P2 $w v / w v$ mouse may give the qualitative impression of a normal cerebellum. The cell death in the EGL can be highlighted, as in the present study, by special methods of tissue processing. We found that when only a basophilic (Nissl) stain is used, the pyknotic cells are less visible than with a combined basophilic and acidophilic stain, such as hemotoxylin and eosin. For these reasons, identification of cell death prior to P4 may have been difficult for previous investigators. From P6 to P8, dead and dying cells are relegated to conspicuous positions in both the $w v / w v$ and $w v /+$ cerebellum. As described by Rakic and Sidman (1973b), "longues" of dead and dying cells are present at the EGL/ML interface in the $\mathrm{P} 6 w v / w v$. In addition, pyknotic cells were also found throughout the superficial layers of the EGL.

Cell death in the $w v / w v$ and $w v /+$ EGL has clear spatial constraints, as might be expected from the known medial (most affected) to lateral (least affected) nature of the weaver phenotype (Herrup and Trenkner, 1987). From P0 to P8, the percentage of pyknotic granule cells in the medial cerebellum (vermis) of the $w v / w v$ mouse is increased relative to that of the lateral aspect of the cerebellum (hemispheres). Also, in the P0 $w v / w v$ cerebellum, pyknotic cells are preferentially present in the posterior lobules of the cerebellar vermis (Fig. $5 B$ ). Thus, within the $w v / w v$ EGL, specific subpopulations of granule cells express the mutant phenotype of cell death at an earlier time. These regions where greater percentages of cell death are seen, the vermis and the posterior lobules, contain granule cell precursors that are among the earliest produced (Altman, 1969).

\section{Characterization of cell death in the EGL}

Granule cell death in the EGL ${ }^{1}$ has been observed in the $+/+$, $w v /+$, and $w v / w v$ cerebella, with the amount of cell death in the $w v / w v$ dramatically increased relative to the amount of cell death seen in the $+/+$ EGL. Calculation of the clearing rate of the granule cells from the EGL of the $w v / w v$ reveals that pyknotic cells are removed from the environment in 4-7 hr. This figure is consistent with the clearing rate of degenerating cells in spinal cord and retina (Hughes, 1961; Wong and Hughes, 1987). Since there seems to be no change in the mitotic index of EGL granule cells in $+/+, w v /+$, or $w v / w v$ (this study; Rezai and Yoon, 1972), it appears that the amount of cell death seen in the EGL can alone account for the granuloprival nature of the weaver mutant ccrcbcllum.

Previous studies have suggested that the type of cell death, nuclear or cytoplasmic, can be used to suggest the cellular processes that lead to cell death (Pilar and Landmesser, 1976; Cunningham, 1982). In our present light microscopic material, pyknotic $w v / w v$ EGL cells have abnormally clumped hetero-

\footnotetext{
'When considering the cell death in the EGL, we recognize that the EGL gives rise to several distinct cell types, including granule cells, basket cells, stellate cells (Miale and Sidman, 1961), and possibly Golgi cells (Hausmann et al., 1985). The adult numbers of granule cells, stellate cells, and basket cells have been determined (Palkovitz et al., 1971a, b; Smolyaninov, 1971), and from these estimates it can be determined that $92 \%$ of the cells derived from the EGL will become granule cells. Sotelo (1975) has demonstrated that basket cells and stellate cells are present in the adult $w v / w v$ cerebellum, further reinforcing a view that the vast majority of dead and dying cells are from the granule cell precursor population.
}

chromatin diagnostic of nuclear cell death (Cunningham et al., 1982) (see Fig. 5C), and is typical of the appearance of pyknotic cycling, immature cells (Wyllie et al., 1980). In fact, dying cells in the $+/+$ EGL have a similar appearance to dead and dying cells in the $w v /+$ and $w v / w v$ EGL. This suggests that the weaver gene may just accentuate a normally occurring process in the developing EGL. Furthermore, naturally occurring cell death is thought to be an intrinsic process of the cell that may manifest itself in a type of cell suicide (Wyllie et al., 1980). This interpretation has significance for proposing a specific cellular process in the action of the weaver gene.

\section{Does the weaver gene affect a specific stage in the differentiation of the granule cell?}

One of the advantages of the cerebellum in the study of development is that discrete developmental events occur at welldefined times. Thus, the identification of the onset of a particular mutant phenotype may suggest the developmental program affected by a mutant gene. Previous studies regarding the cellular event affected by the weaver gene have concluded that there is a defect in cell migration (Rezai and Yoon, 1972; Rakic and Sidman, 1973a, b; Herrup and Trenkner, 1987). Rakic and Sidman $(1973 a, b)$ hypothesized that the ability of granule cells to migrate and their subsequent death were due to aberrant Bergmann glia. Recently, Herrup and Trenkner (1987) proposed that the migratory defect in the granule cells may be present at the initial migration of the granule cell precursors from the area of the germinal trigone superficially over the surface of the cerebellum.

The present studies demonstrate that the $w v / w v$ phenotype of increased cell death is first apparent at the day of birth (P0). Two points suggest that $\mathrm{P} 0$ is the earliest time that the weaver phenotype can be seen. First, estimates of the number of cells in the $\mathrm{P} 0+/+, w v /+$ and $w v / w v$ EGL at $\mathrm{P} 0$ are similar, while significant differences between the 3 groups exist at P2. Second, the early stages of cell death predominate at $\mathrm{P} 0$, while the later stages predominate after $\mathrm{P} 0$. Since the pyknotic cells are cleared relatively quickly (4-7 hr), the time when this could be observed would be in temporal proximity to when cells begin to die.

The identification of $\mathrm{PO}$ as the approximate starting time of weaver phenotypic expression is important since it allows us to focus narrowly on the developmental events occurring at this time. At P0, the cells of the EGL are actively proliferating within the EGL (Fujita, 1967). However, as discussed earlier, there are no apparent differences in the rate of proliferation in the $w v /+$ and $w v / w v$ EGL. A second developmental event, extrapolated from rat development, occurring at around $\mathrm{PO}$ in the murine cerebellum, is the exit of granule cells from their cell cycle (Altman, 1972). Since the weaver gene docs not secm to perturb cellular proliferation, and in light of our observation that a majority of the dead and dying cells are found in EGL zones where granule cells exit their cell cycle, we suggest that the weaver gene acts upon the granule cells at a time after their exit from the cell cycle and before their physical migration from the EGL. Cellular processes in the midst of this time period, including the cell's preparation for migration, would be logical candidates as the primary cellular event affected by the weaver locus.

\section{Conclusions}

Previous studies regarding the mode of action of the weaver gene on cerebellar development have strongly suggested that the 
granule cell is an intrinsic site of mutant gene action (Goldowitz and Mullen, 1982; Hatten et al., 1986; Goldowitz, 1989). By establishing an historical record of the weaver granule cell, we hoped to determine at what time point the weaver gene has its first impact. The first event that seems to set weaver EGL cells apart from the $+1+\mathrm{EGL}$ cells is an increase in the amount of pyknotic cells. The timing and presentation of this weaver mutant phenotype suggests an association with a ccllular cvent proximate to exit from the cell cycle such as cell cycle exit itself, preparation for migration, or axonal outgrowth (Willinger and Margolis, 1985a, b).

The loss of granule cells in the cerebellum is not the only cellular defect that has been described in the $w v / w v$ mouse. Within the cerebellum the Bergmann glia are known to be decreased in number and abnormal in morphology (Rakic and Sidman, 1973a, b) and the Purkinje cells are reduced in number (Rezai and Yoon, 1972; Blatt and Eisenman, 1985; Herrup and Trenkner, 1987). In the midbrain, there is a loss of dopaminergic cells in the $w v / w v$ substantia nigra pars compacta (Schmidt et al., 1982; Roffler-Tarlov and Graybiel, 1987). To further unravel the mysteries of the weaver gene it needs to be determined whether these phenomena are primary sites of weaver gene action. The Bergmann glia defect may, for example, be due to an impaired trophic interaction with the weaver granule cells. The in vitro studies of Hatten et al. (1986) found that weaver granule cells created a dysmorphic appearance in $+/+$ Bergmann glia cells. This interaction may be mediated by a $100 \mathrm{kDa}$ protein called astrotactin, which has been localized to cerebellar granule cells (Edmondson et al., 1988). In general, the Bergmann glia cells may be acutely sensitive to cellular interactions for proper expression of its phenotype (Fisher, 1984). It is more difficult to ascribe the Purkinje cell deficit to such a trophic mechanism. These cells are produced and settle several days before the apparent onset of the weaver granule cell dysfunction. The defect in weaver pars compacta cells would appear even more remote to the problems within the developing weaver cerebellum. The onus of any hypothesis of mutant gene action is to relate all primary effects of the mutant to a single defective gene product that has a critical function in the affected cell(s). A hypothesis that the weaver gene affects EGL cells between the time that they exit the cell cycle and physical migration should be applicable to the other phenotypes of the weaver mouse. In this respect the weaver gene may be thought to adversely, but with variable consequences, affect cells as they exit their cell cycle resulting in a generalized delay in the maturation process. This delay in maturation could prevent certain cells from establishing appropriate environmental relationships, which could not only account for the spatial differences in the weaver phenotype but also the decreased numbers of Purkinje and pars compacta dopaminergic cells (if these prove to be intrinsic sites of weaver gene action). It is important for future analyses to link the weaver defect in Purkinje and substantia nigra pars compacta cells with the cell death observed in cerebellar granule cells to provide a cohesive story of how the weaver gene is involved in CNS development.

\section{References}

Abercrombie, M. (1946) Estimation of nuclear population from microtome sections. Anat. Rec. 94: 239-247.

Altman, J. (1969) Autoradiographic and histological studies of postnatal neurogenesis. III. Dating the time of production and onset of differentiation of cerebellar microneurons in rats. J. Comp. Neurol. 136: 269-294.
Altman, J. (1972) Postnatal development of the cerebellar cortex in the rat. III. Maturation of the components of the granular layer. J. Comp. Neurol. 145: 465-514.

Blatt, G. J., and L. M. Eisenman (1985) A qualitative and quantitative light microscopic study of the inferior olivary complex of normal, reeler, and weaver mutant mice. J. Comp. Neurol. 232: 117-128.

Caviness, V. S., Jr., and P. Rakic (1978) Mechanisms of cortical development: A view from mutations in mice. Annu. Rev. Neurosci. 1: $297-326$.

Cunningham, T. (1982) Naturally occurring neuron death and its regulation by developing neural pathways. Int. Rev. Cytol. 74: 163-186.

Cunningham, T. J., I. M. Mohler, and D. L. Giordano (1982) Naturally occurring neuron death in the ganglion cell layer of the neonatal rat: Morphology and evidence for regional correspondence with neuron death in the superior colliculus. Dev. Brain Res. 2: 203-215.

Edmondson, J. C., R. K. H. Liem, J. E. Kuster, and M. E. Hatten (1988) Astrotactin: A novel neuronal cell surface antigen that mediates neuron-astroglial interactions in cerebellar microcultures. J. Cell Biol. 106: 505-517.

Fisher, M. (1984) Neuronal influence on glial enzyme expression: Evidence from mutant mouse cerebella. Proc. Natl. Acad. Sci. USA 81: 4414-4418.

Fraser, F. J. (1982) A selective stain for mitotic figures, particularly in the developing brain. Stain Technol. 57: 219-224.

Fujita, S. (1967) Quantitative analysis of cell proliferation and differentiation in the cortex of the postnatal mouse cerebellum. J. Cell Biol 32: $277-287$

Fujita, S., M. Shimada, and T. Nakamura (1967) ${ }^{3} \mathrm{H}$-Thymidine autoradiographic studies on the cell proliferation and differentiation in the external and the internal granular layers of the mouse cerebellum. J. Comp. Neurol. 128: 191-208.

Goldowitz, D. (1989) The weaver granuloprival phenotype is due to intrinsic action of the mutant locus in the granule Cell: Evidence from homozygous weaver chimeras. Neuron (in press).

Goldowitz, D., and R. J. Mullen (1982) Granule cell as a site of gene action in the weaver mouse cerebellum: Evidence from heterozygous mutant chimeras. J. Neurosci. 2: 156-172.

Hatten, M. E., R. K. H. Liem, and C. A. Mason (1986) Weaver mouse cerebellar granule neurons fail to migrate on wild-type astroglial processes in vitro. J. Neurosci. 6: 2676-2683.

Hausmann, B., U. Mangold, J. Sievers, and M. Berry (1985) Derivation of cerebellar Golgi neurons from the external granular layer: Evidence from explantation of external granule cells in vivo. J. Comp. Neurol. 232: 511-522.

Herrup, K., and E. Trenkner (1987) Regional differences in cytoarchitecture of the weaver cerebellum suggest a new model for weaver gene action. Neuroscience 23: 871-885.

Hughes, A. (1961) Cell degeneration in the larval ventral horn of Xenopus laevis (Daudin). J. Embryol. Exp. Morphol. 9: 269-285.

Mares, V., Z. Lodin, and J. Srajer (1970) The cellular kinetics of the developing mouse cerebellum. I. The generation cycle, growth fraction, and rate of proliferation of the external granule layer. Brain Res. 23: 323-342.

Miale, I., and R. L. Sidman (1961) An autoradiographic analysis of histogenesis in the mouse cerebellum. Exp. Neurol. 4: 277-296.

Palkovitz, M., P. Magyar, and J. Szentagothai (1971a) Quantitative histological analysis of the cerebellar cortex in the cat. II. Cell numbers and densities in the granular layer. Brain Res. 32: 15-30.

Palkovitz, M., P. Magyar, and J. Szentagothai (1971b) Quantitative histological analysis of the cerebellar cortex in the cat. III. Structural organization of the molecular layer. Brain Res. 34: 1-18.

Pilar, G., and L. Landmesser (1976) Ultrastructural differences during embryonic cell death in normal and peripherally derived ciliary ganglia. J. Cell Biol. 68: 339-356.

Rakic, P. (1971) Neuron-glia relationship during granule cell migration in developing cerebellar cortex. A Golgi and electronmicroscopic study in macacus rhesus. J. Comp. Neurol. 141: 283-312.

Rakic, P., and R. L. Sidman (1973a) Sequence of developmental abnormalities leading to granule cell deficit in cerebellar cortex of weaver mutant mice. J. Comp. Neurol. 152: 103-132.

Rakic, P., and R. L. Sidman (1973b) Weaver mutant mouse cerebellum: Defective neuronal migration secondary to abnormality of Bergmann glia. Proc. Natl. Acad. Sci. USA 70: 240-244.

Ramón y Cajal, S. (1960) Studies on Vertebrate Neurogenesis, L. Guth, trans., Thomas, Springfield, IL. 
Rezai, Z., and C. H. Yoon (1972) Abnormal rate of granule cell migration in the cerebellum of "weaver" mutant mice. Dev. Biol. 29 17-26.

Roffler-Tarlov, S., and A. M. Graybiel (1987) The postnatal development of the dopamine-containing innervation of dorsal and ventral striatum: Effects of the weaver gene. J. Neurosci. 7: 2364-2372.

Schmidt, M. J., B. D. Sawyer, K. W. Perry, R. W. Fuller, M. M. Foreman, and B. Ghetti (1982) Dopamine deficiency in the weaver mutant mouse. J. Neurosci. 2: 376-380

Sidman, R. L., M. C. Green, and S. H. Appel (1965) Catalog of the Neurological Mutants of the Mouse, Harvard U. P., Cambridge, MA.

Smolyaninov, V. V. (1971) Some special features of organization of the cerebellar cortex. In Models of the Structural-Functional Organization of Certain Biological Systems, I. M. Gelfand, V. S. Garfinkel, S. V. Fornin, and M. L. Tsetlin, eds., pp. 251-325, MIT Press, Cambridge, MA.

Sotelo, C. (1975) Anatomical, physiological and biochemical studies of the cerebellum from mutant mice. II. Morphological study of cerebellar cortical neurons and circuits in the weaver mouse. Brain Res. 94: $19-44$.
Sotelo, C., and J. P. Changeux (1974) Bergmann fibers and granule cell migration in the cerebellum of homozygous weaver mutant mice. Brain Res. 77: 484-491.

Trinkhaus, J. P. (1984) Cells into Organs. The Forces that Shape the Embryo, 2nd ed., Prentice-Hall, Englewood Cliffs, NJ.

Willinger, M., and D. M. Margolis (1985a) Effect of the weaver (wv) mutation on cerebellar neuron differentiation. I. Qualitative observations of neuron behavior in culture. Dev. Biol. 107: 156-172.

Willinger, M., and D. M. Margolis (1985b) Effect of the weaver (wv) mutation on cerebellar neuron differentiation. II. Quantitation of neuron behavior in culture. Dev. Biol. 107: 173-179.

Winer, B. J. (1961) Statistical Principles in Experimental Design, McGraw-Hill, New York.

Wong, R. O. L., and A. Hughes (1987) Role of cell death in the topogenesis of neuronal distributions in the developing cat retinal ganglion cell layer. J. Comp. Neurol. 262: 496-511.

Wyllie, A. H., J. F. R. Kerr, and A. R. Currie (1980) Cell death: The significance of apoptosis. Int. Rev. Cytol. 68: 251-306. 